\title{
Pathogen Prevalence and Human Mate Preferences
}

\author{
Steven W. Gangestad
}

University of New Mexico

David M. Buss

University of Michigan

\begin{abstract}
Members of host species in pathogen-host coevolutionary races may be selected to choose mates who possess features of physical appearance associated with pathogen resistance. Human data from 29 cultures indicate that people in geographical areas carrying relatively greater prevalences of pathogens value a mate's physical attractiveness more than people in areas with relatively little pathogen incidence. The relationship between pathogen prevalence and the value people place on physical attractiveness remained strong even after potential confounds such as distance from the equator, geographical region, and average income were statistically controlled for. Discussion focuses on potential limitations of the data, alternative explanations for the findings, and the nature of adaptations to the problems posed by pathogen prevalence.
\end{abstract}

KEY WORDS: Mate preferences; Physical attractiveness; Parasites; Host-parasite coevolution.

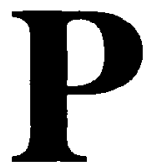
athogens may profoundly affect the evolution of their hosts (e.g., Anderson and May 1982; Clarke 1976; Hamilton 1980, 1982; Hamilton and Zuk 1982; Tooby 1982). Pathogens with extremely short intergenerational times have been claimed to be responsible for no less an evolutionary outcome than sexual reproduction (Hamilton 1980; Seger and Hamilton 1986). Pathogens that possess intermediate intergenerational times such that parasite-host coevolution maintains additive genetic variance in host fitness may influence sexual selection pressures (Hamilton and Zuk 1982). Specifically, heritable differences in pathogen resistance may prompt "good genes" sexual selection-selection for mate preferences based on mate qualities that discriminate individuals with regard to their pathogen resistance (e.g., Andersson 1986; Grafen 1990; Heywood 1989; Iwasa, Pomiankowski, and Nee 1991; Pomiankowski 1987). Although empiri-

Received February 24, 1992; revised November 24, 1992.

Address reprint requests and correspondence to: Steven W. Gangestad, Department of Psychology, University of New Mexico, Albuquerque, NM 87131, or David M. Buss, Department of Psychology, University of Michigan, Ann Arbor, MI 48109-3946. 
cal data relevant to these notions is inconclusive (Read 1990), supportive evidence is beginning to accumulate from studies of nonhuman species (see, for instance, Hausfater and Thornhill 1990; Møller 1990a,b).

Low (1990) applied these notions to a study of humans. Assuming that heritable variation in mate quality leads females to be willing to partly sacrifice paternal investment for genetic mate quality (Trivers 1972), Low predicted that human societies in pathogen prevalent environments should be more polygynous (e.g., a greater percentage of women should be in polygynous marriages) than societies in environments with relatively low pathogen stress. Analysis of 186 societies of the Standard Cross-Cultural Sample (Murdock and White 1969) supported the prediction. While not identifying any specific feature that bestows multiple mates upon males in high pathogen stress areas, Low speculated that physical appearance may be one indicator of mate quality.

Humans choose mates, partly and to varying extents, on the basis of physical attractiveness (Buss 1985, 1989; Symons 1979). Might these preferences have evolved partly because of sexual selection pressures prompted by host-parasite coevolutionary maintenance of additive genetic variance? If host-parasite coevolution has maintained additive genetic variance in fitness, then increased prevalence of pathogens ought to be associated with increased importance of choosing a pathogen-resistant mate. Moreover, if attractiveness relates to pathogen resistance, then individuals' ratings of the importance of attractiveness as a criterion of mate choice should relate to pathogen prevalence across cultures.

\section{THE STUDY}

To test this prediction, we examined a data base of individuals from 37 different societies located on six continents and five islands (see Buss 1989 for details of the sample). Each subject rated the importance of 18 attributes (from $0=$ irrelevant or unimportant to $3=$ indispensable) as criteria for mate selection, including the target variable, "good looks." Obviously, migration occurs and hence not all participants or their relatively close ancestors were from areas in which they resided. Nonetheless, most respondents in most samples probably had ancestors who resided in the general area for at least several generations. We excluded several countries for which this assumption was less certain (U.S. [mainland], U.S. [Hawaii], Canada [English], Canada [French], New Zealand, Australia, South Africa [whites], and Israel [Jewish]); 29 samples comprising 7139 individuals were analyzed.'

Pathogen stress was indexed through Low's (1990) procedures. On the basis of world distribution maps (Faust and Russell 1964; Simmons et al. 1944; Warren and Mahmoud 1984), the incidence of each of seven pathogen

\footnotetext{
${ }^{1}$ Being more strict on this criterion and eliminating South American countries only strengthens our predicted association.
} 
groups in all countries represented was estimated on a 3-point scale: "1" = no record of occurrence; " 2 " = record of occurrence, but no indication of severe levels; " 3 " = severe levels of occurrence. The seven pathogens were: (1) leishmanias (Leishmania tropica, L. braziliensis, L. donovani); (2) trypanosomes (Trypanosoma gambiense, T. rhodesiense); (3) malaria (Plasmodium vivax, $P$. ovale, $P$. maliariae, $P$. falciparum); (4) schistosomes (Schistosoma japonicum, S. mansoni, S. haematobium); (5) filariae (Wucheria bancrofti, Brugia malayi); (6) spirochetes (Borrelia duttoni, B. recurrentis, Treponema); (7) leprosy (Mycobacterium leprae). Low (1990) chose these pathogens because they meet Hamilton's criteria of an acute, possibly fatal stage of infection and long-term debilitation or recurrence of acute episodes (see Low 1990 for a description of each). Moreover, worldwide records exist for them. When possible, we relied upon maps of prevalences before the introduction of modern medicine. A sum of the seven pathogen prevalences constituted a pathogen stress index (Table 1). ${ }^{2}$

Correlational analyses treating country as the unit of analysis were performed. These analyses revealed a significant positive relation between pathogen prevalence and average attractiveness rating across countries, $r=$ $.38, p<.05 .^{3}$ This relation was unmoderated by sex of rater, $t<1, n s$.

To rule out potential confounding variables, we conducted additional analyses. First, pathogen prevalence is higher in the tropics and so we controlled for distance from the equator. Using world maps, we estimated (to the nearest five degrees) the latitude of each region sampled and expressed each latitude in terms of distance from the equator (i.e., as absolute latitude). Second, pathogen prevalence is higher on certain continents that may be associated with various factors (e.g., racial ancestry), so we controlled for gcographical region. Countrics were divided into five gcographical regions (Africa, Europe, East Asia, South America, Central Asia) and dummy variables that account for variance between these regions were created (Neter and Wasserman 1974). Third, pathogen prevalence appears to be associated with average income. Using figures listed in the World Almanac and Book of Facts 1989 (1988), we estimated average income (expressed in U.S. dollars). ${ }^{4}$

\footnotetext{
2 These pathogens may not represent the full range of parasites that would fit Hamilton's criteria. Nonetheless, pathogen prevalences tend to covary across countries; those countries with high prevalences on one tend to also have high prevalences on others (see Table 1). As a result, estimates of pathogens prevalences based on these seven parasites probably generalize to an extent to other relevant parasites. We estimated Cronbach's coefficient of generalizability (alpha) to be .83 for our index of pathogen prevalence.

${ }^{3} p$-Values reported in this paper were derived from randomization tests. Randomization tests are based on sampling distributions for test statistics derived from actual observed distributions and hence do not assume particular distributions of observations (e.g., normality). Moreover, they control for nonindependence of sampling (Smouse, Long, and Sokal 1986).

${ }^{4}$ Actual years for the figures ranged from 1982-1986, approximately the years that the data were collected. Unfortunately, we do not know the incomes of the actual participants and hence simply used the country averages. For one country in particular, this estimate seemed inappropriate. South African incomes in general (on average, $\$ 4000$ in U.S. dollars) do not retlect incomes of South African Zulus. We figured that Zulus' income was closer to that of other African countries represented in the sample, Nigeria $(\$ 790)$ and Zambia $(\$ 570)$. We used the figure $\$ 1000$ for the analysis reported. The results did not change in any meaningful way when we substituted figures ranging from $\$ 500$ to $\$ 4000$.
} 
Table 1. Pathogen Prevalence and Importance of Physical Attractiveness Ratings in 29 Cultures

\begin{tabular}{|c|c|c|c|c|c|c|c|c|c|c|c|}
\hline \multirow[b]{2}{*}{ Culture } & \multicolumn{8}{|c|}{ Pathogen Incidence } & \multicolumn{3}{|c|}{ PA Ratings } \\
\hline & Lei & Trp & Mal & Sch & Fil & Spr & Lep & TOT & $\mathbf{M}$ & $\mathbf{F}$ & TOT \\
\hline \multicolumn{12}{|l|}{ Africa } \\
\hline Nigeria & 3 & 3 & 3 & 3 & 3 & 2 & 3 & 20 & 2.24 & 1.82 & 4.06 \\
\hline Zambia & 1 & 3 & 3 & 3 & 3 & 3 & 3 & 19 & 2.23 & 1.65 & 3.88 \\
\hline S. Africa (Zulu) & 1 & 1 & 1 & 1 & 1 & 1 & 2 & 8 & 1.17 & .88 & 2.05 \\
\hline \multicolumn{12}{|l|}{ Europe } \\
\hline Belgium & 1 & 1 & 2 & 1 & 1 & 3 & 1 & 10 & 1.78 & 1.28 & 3.06 \\
\hline England & 1 & 1 & 1 & 1 & 1 & 3 & i & 9 & 1.96 & 1.36 & 3.32 \\
\hline W. Germany & 1 & 1 & 1 & 1 & 1 & 2 & 1 & 8 & 1.92 & 1.32 & 3.24 \\
\hline Spain & 2 & 1 & 2 & 1 & 2 & 3 & 1 & 12 & 1.91 & 1.24 & 3.15 \\
\hline Italy & 3 & 1 & 2 & 1 & 2 & 3 & 1 & 13 & 2.00 & 1.64 & 3.64 \\
\hline Greece & 3 & 1 & 3 & 1 & 2 & 3 & 2 & 15 & 2.22 & 1.94 & 4.16 \\
\hline Bulgaria & 2 & 1 & 2 & $i$ & 2 & 3 & 1 & 12 & 2.39 & 1.95 & 4.34 \\
\hline Yugoslavia & 2 & 1 & 3 & 1 & 2 & 3 & 1 & 13 & 2.20 & 1.74 & 3.94 \\
\hline France & 2 & 1 & 1 & 1 & 1 & 2 & 1 & 9 & 2.08 & 1.76 & 3.84 \\
\hline Netherlands & 1 & 1 & 1 & 1 & 1 & 2 & 1 & 8 & 1.76 & 1.21 & 2.97 \\
\hline Sweden & $i$ & $i$ & 1 & 1 & 1 & 1 & 1 & 7 & 1.65 & 1.46 & 3.11 \\
\hline Finland & $i$ & 1 & 1 & 1 & 1 & 1 & 1 & 7 & 1.56 & .99 & 2.55 \\
\hline Poland & 1 & 1 & 1 & 1 & 1 & 3 & 1 & 9 & 1.93 & 1.77 & 3.70 \\
\hline Estonia & 1 & 1 & 2 & 1 & 1 & 2 & 1 & 9 & 2.27 & 1.63 & 3.90 \\
\hline Norway & 1 & 1 & 1 & 1 & 1 & 1 & 1 & 7 & 1.87 & 1.32 & 3.19 \\
\hline Ireland & 1 & 1 & 1 & 1 & 1 & 3 & 1 & 9 & 1.87 & 1.22 & 3.09 \\
\hline \multicolumn{12}{|l|}{ Middle East/India } \\
\hline Israel (Pale.) & 3 & 1 & 2 & 1 & 1 & 3 & 2 & 13 & 2.38 & 1.47 & 3.85 \\
\hline Iran & 2 & 1 & 3 & 1 & 1 & 3 & 2 & 13 & 2.07 & 1.69 & 3.76 \\
\hline India & 2 & 1 & 3 & 1 & 2 & 3 & 3 & 15 & 2.03 & 1.97 & 4.00 \\
\hline \multicolumn{12}{|l|}{ Far East } \\
\hline China & 2 & 1 & 3 & 2 & 2 & 3 & 2 & 15 & 2.06 & 1.59 & 3.65 \\
\hline Japan & 1 & 1 & 2 & 3 & 2 & 2 & 2 & 13 & 1.50 & 1.09 & 2.59 \\
\hline Taiwan & 1 & 1 & 3 & 3 & 2 & 3 & 2 & 15 & 1.76 & 1.28 & 3.04 \\
\hline Indonesia & 1 & 1 & 3 & 1 & 3 & 2 & 3 & 14 & 1.81 & 1.36 & 3.17 \\
\hline \multicolumn{12}{|l|}{ South America } \\
\hline Brazil & 3 & 2 & 3 & 3 & 3 & 1 & 2 & 17 & 1.89 & 1.68 & 3.57 \\
\hline Columbia & 3 & 2 & 2 & 2 & 1 & 3 & 2 & 15 & 1.56 & 1.22 & 2.78 \\
\hline Venezuela & 2 & 2 & 3 & 3 & 3 & 3 & 2 & 18 & 1.76 & 1.27 & 3.03 \\
\hline
\end{tabular}

Key: Lei = Leishmania, Trp = Trypanosoma, Mal = Malaria, Sch = Schistosoma, Fil = Filaria, Spr $=$ Spirochetes, Lep $=$ Leprosy.

$1=$ No record of occurrence.

$2=$ Records of occurrence, but no indication of severe levels.

$3=$ Severe levels of occurrence.

When the effects of these potential confounding variables were statistically controlled for, pathogen prevalence substantially correlated with average attractiveness rating across countries, $r=.72, p<.001$. This relation was highly significant for each sex $(p s<.002)$ and was unmoderated by sex, $t<1, n s$. Apparently, factors associated with latitudinal or regional variation (e.g., genetic or cultural drift) or with average income cannot account for the relation between pathogen prevalence and preference for attractive mates. Indeed, when variation associated with those variables is removed, the relation becomes stronger. ${ }^{5}$

${ }^{5}$ When variation due to latitudinal or regional differences was controlled for, income had no 


\section{DISCUSSION}

These results are consistent with the hypotheses that (1) in the course of human history, pathogen resistance has significantly contributed to individual differences in mate quality, and (2) at least within environments in which pathogen incidence has been high, humans may well have evolved, through "good genes" sexual selection, to assess pathogen resistance in potential mates on the basis of physical attractiveness.

\section{Limitations of the Data}

These data are not without limitations. First, although we controlled for potential confounds, there may be a critical confound we did not assess. Second, we do not know the residence histories of our participants. As we discussed, most of our participants probably lived or had ancestors who lived in the area in which they were sampled, but surely some did not. Third, we cannot be sure that our estimates of pathogen prevalence are fully adequate. Some parasites may not have been included (although see footnote 2) and some important disease outbreaks may not be represented in our estimates (e.g., previous afflictions of malaria or leprosy in Europe). Moreover, the precise time frame of pathogen prevalence relevant to notions of sexual selection (e.g., the last 50 years, 100 years, 1000 years, etc.) depends upon the exact nature of the adaptations that might be the outcome of sexual selection (see "The Nature of Underlying Adaptations" below). Finally, we do not know the criteria of attractiveness our respondents applied; the importance of some specific criteria may vary with pathogen prevalence whereas the importance of others may not (see "Alternate Explanations" below).

In general, one would expect that flaws in our measures would hurt, not help, chances of these measures relating to one another. Nonetheless, these limitations suggest that further work on the relation between preferences for attractiveness and pathogen prevalence is needed.

\section{Alternative Explanations}

Alternative explanations exist for phenomena potentially due to "good genes" sexual selection, and the present case is no exception. The most notable alternative is the parasite avoidance hypothesis (Hamilton 1990; Moller 1990; Kirkpatrick and Ryan 1991). Physical attractiveness may be a

effect on preference for attractiveness independent of pathogen prevalence. These results were somewhat different for men and women, however. Independent of other variables, income did negatively relate to females' preference for attractiveness at a marginally significant level, partial $r=-.35, p<.10$. Income did not relate to males' prcference for attractiveness. If most income in these countries is generated by men, this result makes sense: The less income men make, the more women care about factors not related to income, such as attractiveness. 
marker of current health and lack of parasite load. Given that parasites can be contracted from mates, individuals may avoid mating with persons who carry pathogens.

Across cultures, people find explicit evidence of disease and deformity unattractive (Ford and Beach 1951), supporting the notion that individuals avoid choosing diseased mates (see also Symons 1979). Nonetheless, certain considerations suggest that factors other than disease avoidance may be responsible for our tindings. Most potential mates are not afflicted with serious parasites and individuals make important discriminations in the attractiveness of non-afflicted persons. Some of the features along which individuals discriminate facial attractiveness in nondiseased individuals may be related to parasite resistance. For instance, two features associated with male attractiveness across a variety of cultures are prominent cheekbones and chins (Cunningham 1992; Cunningham, Barbee, and Pike 1990). These features appear to develop during and after puberty in response to testosterone production (e.g., Sherwood 1989). Fölstad and Karter (1992) recently argued that common forms of "honest advertisement" of pathogen resistant "good genes"' are handicaps placed directly upon the immune system of the individual; pathogen susceptible individuals cannot afford the costs of such handicaps. In many vertebrates, including humans, testosterone is a potent immunosuppressant (e.g., Alexander and Stimson 1988; Grossmann 1985). The fact that certain attractive features are associated with immunosuppression fits nicely with "good genes" sexual selection.

Also, preference for yet other features associated with attractiveness may have evolved in response to host-parasite coevolution. Charlesworth (1988) showed that, under fluctuating selection associated with host-parasite coevolution, the log mean fitness of heterozygotes exceeds the mean fitness of the population and, hence, mate preferences for heterozygotes are favored. With respect to certain dimensions, individuals prefer faces with average features (e.g., Langlois and Roggman 1990; Cunningham et al. 1990). Average facial features are associated with heterozygosity at genetic loci associated with facial morphology; these loci appear to be plentiful (Gangestad, Simpson, and DiGeronimo 1992), and hence preferences for facial averageness could have evolved through sexual selection pressures prompted by host-parasite coevolution.

A second alternative hypothesis is the efficient parent hypothesis (e.g., Borgia 1986; Hamilton 1990; Moller 1990b). Individuals may have evolved to prefer mates who are pathogen free and pathogen resistant because they make better immediate caregivers. To the extent that attractiveness involves handicapping (e.g., Fölstad and Karter 1992), Hamilton (1990) considers this hypothesis implausible. Close, extended observations of potential mates' performance under hardship would seem to provide a better indication of good parenting than do immunosuppressive handicaps. Moreover, the efticient parent hypothesis does not explain Low's (1990) finding of the associa- 
tion between polygyny and pathogen prevalence as well as the "good genes" hypothesis.

Despite evidence that concerns for parasite avoidance or choosing a mate who is an efficient parent may not fully account for available findings, these explanations cannot be ruled out at this time. Further research is needed.

\section{The Nature of Underlying Adaptations}

Unresolved is the precise nature of the adaptations responsible for the relation between pathogen incidence and value of attractiveness. Several possibilities are: (1) selection pressures favoring individuals with genotypes predisposing mate choice on the basis of attractiveness have been more intense in areas of high pathogen incidence; (2) selection pressures extending back among prehuman primates produces species-wide facultative mechanisms enabling individuals to track pathogen stress and, accordingly, adjust their mate choice criteria; (3) trends of local cultural evolution based upon observations of differential success of families have been influenced by effects arising from local parasite prevalence; (4) the association is caused by greater variance of parasite affliction in pathogen prevalent areas; where parasites are more prevalent, variance in parasite affliction is greater and, hence, grcater weight is accorded to attractiveness as a criterion of mate choice. Further research is now needed on mate preferences, cues to physical attraction and repulsion, and other potential mechanisms that might have evolved to deal with the adaptive problems posed by pathogen prevalence.

\section{REFERENCES}

Alexander, J. and Stimson, W.H. Sex hormones and the course of parasitic infection. Parasitology Today 4: 189-193, 1988.

Anderson, R.M. and May, R.M. Coevolution of hosts and parasites. Parasitology 85: 411-426, 1986.

Andersson, M. Evolution of condition-dependent sex ornaments and mating preferences: Sexual selection based on viability differences. Evolution 40: 804-816, 1986.

Borgia, G. Satin bowerbird parasites: A test of the bright male hypothesis. Behavioral Ecology and Sociobiology 19: 355-358, 1986.

Buss, D.M. Human mate selection. American Naturalist 73: 47-51, 1985.

- Sex differences in human mate preferences: Evolutionary hypotheses tested in 37 cultures. Behavioral and Brain Sciences 12: 1-14, 1989.

Charlesworth, B. The evolution of mate choice in a fluctuating environment. Journal of Theoretical Biology 130: 191-204, 1988.

Clarke, B. The ecological genetics of host-parasite relationships. In Genetic Aspects of HostParasite Relationships, A.E.R. Taylor and R. Muller (Eds.). Oxford: Blackwell, 1976.

Cunningham, M.R. A psycho-evolutionary, multiple-motive interpretation of physical attractiveness. Talk delivered at the annual convention of the American Psychological Association, San Francisco, 1991.

Cunningham, M.R., Barbee, A.P., and Pike, C.L. What do women want? Facialmetric assess- 
ment of multiple motives in the perception of male facial physical attractiveness. Journal of Personality and Social Psychology 59: 61-72, 1990.

Faust, E.C. and Russell, P.F. Craig and Faust's Clinical Parasitology, Philadelphia: Lea \& Febiger, 1964.

Fölstad, I. and Karter, A.J. Parasites, bright males, and the immunocompetence handicap. American Naturalist 139: 603-622, 1992.

Ford, C.S. and Beach, F.A. Patterns of Sexual Behavior, New York: Harper \& Row, 1951.

Gangestad, S.W., Simpson, J.A., and DiGeronimo, K. On the relation between personality and physical attractiveness: Test of an evolutionary hypothesis. Manuscript under review, 1992.

Grafen, A. Biological signals as handicaps. Journal of Theoretical Biology 144: 517-546, 1990.

Grossmann, C.J. Interactions between the gonadal steroids and the immune system. Science 227: 257-261, 1985.

Hamilton, W.D. Sex versus non-sex versus parasite. Oikos 35: 282-290, 1980.

- Pathogens as causes of genetic diversity in their host populations. In Population Biology of Infectious Diseases, R.M. Anderson and R.M. May (Eds.). New York: SpringerVerlag, 1982.

Mate choice near and far. American Zoologist 30: 341-352, 1990.

and Zuk, M. Heritable true fitness and bright birds: A role for parasites? Science 218: 384-387, 1982.

Hausfater, G. and Thornhill, R. Parasites and sexual selection. American Zoologist 30: 2, 1990.

Heywood, J.S. Sexual selection by the handicap principle. Evolution 43: 1387-1397, 1989.

Iwasa, Y., Pomiankowski, A., and Nee, S. The evolution of costly mate preferences. II. The "handicap" principle. Evolution 45: 1431-1442, 1991.

Kirkpatrick, M. and Ryan, M.J. The evolution of mating preferences and the paradox of the lek. Nature 350: 33-38, 1991.

Langlois, J.H. and Roggman, L.A. Attractive faces are only average. Psychological Science 1: $115-121,1990$.

Low, B.S. Marriage systems and pathogen stress in human societies. American Zoologist 30: 325-339, 1990.

Møller, A.P. Effects of a haematophagus mite on the barn swallow (Hirundo rustica): A test of the Hamilton and Zuk hypothesis. Evolution 44:771-784, 1990a.

- Parasites and sexual selection: Current status of the Hamilton and Zuk hypothesis. Journal of Evolutionary Biology 3: 319-328, $1990 \mathrm{~b}$.

Murdock, G.P. and White, D.R. Standard cross-cultural sample. Ethnology 8: 329-369, 1969.

Neter, J. and Wasserman, W. Applied Linear Statistical Models, Georgetown, Ontario: Irwin, 1974.

Read, N.F. Parasites and the evolution of host sexual behaviour. In Parasitism and Host Behav iour, C.J. Barnard and J.M. Behnke (Eds.). London: Taylor and Francis, 1990.

Seger, J. and Hamilton, W.D. Parasites and sex. In The Evolution of Sex: An Examination of Current Ideas, R.E. Michod and B.R. Levin (Eds.). Sunderland, MA: Sinauer Associates, 1986.

Sherwood, L. Human Physiology: From Cells to Systems, St. Paul, MN: West, 1989.

Simmons, I.S., Whayne, T.F., Anderson, G.W., and Horack. H.M. Global Epidemiology: A Geography of Disease and Sanitation, Philadelphia: Lippincott, 1944.

Smouse, P.T., Long, J.C., and Sokal, R.R. Multiple regression and correlation extensions of the Mantel test of matrix correspondence. Systematic Zoology 35: 627-632, 1986.

Symons, D. The Evolution of Human Sexuality, Oxford: Oxford University Press, 1979.

Tooby, J. Pathogens, polymorphisms, and the evolution of sex. Journal of Theoretical Biology 97: $557-576,1982$.

Trivers, R. Parental investment and sexual selection. In Sexual selection and the descent of man, 1871-197I, B. Campbell (Ed.). Chicago: Aldine, 1972.

Warren, K.S., Mahmoud, A.A.F. Tropical and Geographical Medicine, New York: McGrawHill, 1984.

World Almanac and Book of Facts 1989, New York: Pharos, 1988. 